\title{
Kearifan Lokal Dalam Bentuk Sanksi Hukum Bagi Pelaku Pada Masyarakat Adat Batak Bagian Selatan
}

\author{
Anwar Sadat Harahap*1), Ahmad Laut Hasibuan'1), Taufik Siregar ${ }^{3)}$ \\ 1) 2) Fakultas Hukum, Universitas Muslim Nusantara Al-Wasliyah, Indonesia \\ 3) Fakultas Hukum, Universitas Medan Area, Indonesia
}

Diterima September 2017; Disetujui November 2017; Dipublikasikan Januari 2018

\begin{abstract}
Abstrak
Nilai-nilai kearifan lokal pada masyarakat Adat Batak Bagian Selatan, memiliki makna yang dalam, baik dari segi adat maupun agama, sehingga perlu dilestarikan untuk menciptakan masyarakat yang peduli dengan sesama dan lingkungan. Tulisan ini bertujuan untuk mengetahui kearifan lokal masyarakat Adat Batak Bagian Selatan dalam bentuk sanksi hukum bagi pelaku. Dalam setiap pelanggaran atau kejahatan yang dilakukan di tengah- tengah masyarakat, telah ada aturan jenis sanksinya sebagaimana yang telah tertuang dalam Surat Tumbaga Holing yang menjadi sumber rujukan hukum adat masyarakat adat Batak Bagian Selatan. Di dalam Surat tersebut, terdapat beberapa sanksi yang penuh dengan kearifan local yang dijatuhkan kepada orang yang memicu timbulnya konflik sosial dalam masyarakat. Kearifan lokal ini perlu disosialisasikan pada generasi penerus dengan mempelajarinya mulai tingkat dasar sampai perguruan tinggi sehingga tetap terjaga kelestariannya.

Kata Kunci: Kearifan Lokal, Sanksi Hukum, Pelaku, Adat Batak Bagian Selatan
\end{abstract}

\begin{abstract}
The values of local wisdom in Indigenous Batak South, have deep meaning, both in terms of custom and religion, so it needs to be conserved to create a community that cares about each other and the environment. This paper aims to know the local wisdom of Indigenous Batak South in the form of legal sanctions for the perpetrators. In every violation or crime committed within the community, there has been a rule of sanction type as set forth in the Slaughter of Holing which is the source of reference of customary law of indigenous peoples of South Batak. In the letter, there are several sanctions that are full of local wisdom that is imposed on people who trigger social conflicts in society. This local wisdom needs to be socialized in the next generation by studying it from the basic level until the university so as to maintain its sustainability.

Keywords: Local Wisdom, Legal Sanctions, Performers, Southern Batak Custom
\end{abstract}

How to Cite: Anwar Sadat Harahap, Ahmad Laut Hasibuan, Taufik Siregar, (2018), Kearifan Lokal Dalam Bentuk Sanksi Hukum Bagi Pelaku Pada Masyarakat Adat Batak Bagian Selatan, Anthropos: Jurnal Antropologi Sosial dan Budaya, 3 (2): 122-130

*Corresponding author: p-ISSN 2460-4585

E-mail: anwarsadathrp@yahoo.com e-ISSN 2460-4593 


\section{PENDAHULUAN}

Tidak bisa dipungkiri bahwa di Indonesia telah terjadi berbagai konflik sosial yang melibatkan antara kelompok masyarakat yang satu dengan kelompok masyarakat lainnya, seperti: perang saudara di Poso (1998 - 2001), Ambon (1999 - 2002), Maluku Utara (2000), konflik Sampit (2001), kerusuhan malam lebaran Idul Fitri tanggal 2 November 2006 di desa Air Bara antara masyarakat pribumi Bangka dengan warga Air Sampik (mayoritas suku Jawa) yang menyebabkan beberapa rumah warga Air Sampik hangus terbakar, kerusuhan di Lampung Selatan Mesuji (2012) dan lainnya, kerusuhan pecah di kawasan Jakarta Utara, tepatnya di sekitar Luar Batang, Penjaringan, Jumat (4/11/2016) dan lainnya.

Mayoritas masalah tersebut timbul, karena berpangkal pada selain kurang tegas, adil dan manfaatnya materi pengaturan hukum tentang pencegahan konflik sosial yang dirasakan masyarakat selama ini, juga masyarakat adat beserta kearifan lokal yang dimilikinya belum dilibatkan dalam pencegahahan konflik sosial secara formal di tengah-tengah masyarakat. Tidak bisa dipungkiri bahwa kehidupan berbagai masyarakat adat yang ada di Indonesia, seperti masyarakat adat Batak di Sumatera Utara, masyarakat adat Melayu di Riau, masyarakat adat Minangkabau di Sumatera Barat, masyarakat adat Jawa di Yogyakarta dan masyarakat adat lainnya sering menghadapi cobaan dan tantangan, seperti meledaknya bom di tempat-tempat ibadah, konflik pembagian warisan, konflik akibat perkawinan, konflik pelaksanaan pilkada, pertikaian antar pemuda yang berbeda agama dan suku dan berbagai konflik lainnya.

Sebagian besar konflik tersebut, dapat diatasi dan dicegah oleh masyarakat adat melalui hukum adat yang terdapat dalam kearifan lokal masing-masing, sehingga tidak sampai menimbulkan konflik yang berkepanjangan di tengah-tengah masyarakat. Sebab dalam konsep kearifan lokal, telah diatur di dalamnya tentang: 1) sistem dan prosedur pencegahan dan penyelesaian konflik sosial, 2) proses pelaksanan mediasi dalam pencegahan konflik sosial, 3) strategi yang dilakukan tokoh adat dalam pencegahan konflik sosial, 4) sistem peradilan dalam penyelesaian konflik sosial, dan 6) jenis sanksi yang dijatuhkan terhadap pelaku yang memicu munculnya konflik sosial.

Berbagai aturan tersebut di atas telah diajarkan kepada seluruh anggota masyarakat adat sejak kecil, sehingga materinya dipahami, dihormati dan diamalkan dalam kehidupan sehari-hari karena sesuai dengan cita-cita hukum (rechtsidee) dan perasaan hukum (rechtsgevool) masyarakat adat. Selain itu, keberadaan tokoh adat dalam suatu masyarakat adat masih sangat dihormati dan disegani, sehingga perintahnya dilaksanakan dan larangannya ditinggalkan.

Pencegahan konflik sosial secara arif dan bijaksana bukanlah barang jadi yang datang begitu saja, tetapi ia merupakan proyek sosial yang mesti dibina dan diarahkan, sehingga tercipta keharmonisan sosial, sifat toleransi dan adanya saling pengertian dan penghormatan antara masyarakat yang satu dengan masyarakat lainnya (Harahap, 2013: 96-99).

Bangsa Indonesia adalah bangsa besar yang memiliki keragaman budaya. Setiap budaya memiliki kearifan-kearifan tersendiri dalam menyikapi permasalahan hidup yang dihadapi, termasuk di dalamnya kearifan dalam menyelesaikan konflik (Ilyas. 2014: 1221).

Tradisi dan kearifan lokal yang masih ada serta berlaku di masyarakat, berpotensi untuk dapat mendorong keinginan hidup rukun dan damai. Hal itu karena kearifan tradisi lokal pada dasarnya mengajarkan perdamaian dengan sesamanya, lingkungan, dan Tuhan (Sriyanto. 2007: 286-301).

Menurut Jati (2013: 397)bahwa ada lima peran vital kearifan lokal sebagai media resolusi konflik keagamaan, yakni: 1) Kearifan lokal sebagai penanda identitas sebuah komunitas. 2) Kearifan lokal sendiri menyediakan adanya aspek kohesif berupa elemen perekat lintas agama, lintas warga, dan kepercayaan. 3) Kearifan lokal sebagai bagian dari resolusi konflik alternatf justru lebih ke arah mengajak semua pihak untuk berunding dengan memanfaatkan kedekatan emosi 
maupun kultural. 4) Kearifan lokal berfungsi mendorong terbangunnya kebersamaan. 5) Kearifan lokal akan mengubah pola pikir dan hubungan timbal balik individu dan kelompok, dengan meletakkan di atas kebudayaan yang dimiliki.

Potensi bangsa yang begitu besar haruslah dikelola dengan benar dan adil, sebab bila dibiarkan berjalan apa adanya dan menurut selera masing-masing, bukan mustahil akan menimbulkan konflik yang berkepanjangan di tengah-tengah masyarakat yang dapat berakibat pada munculnya tindakan amuk masa, bentrokan dan tawuran yang dapat menelan korban jiwa.

\section{HASIL DAN PEMBAHASAN}

Masyarakat adat Batak telah memiliki seperangkan aturan yang tertuang melalui pranata Surat Tumbaga Holing. Siapa saja yang melakukan tindakan yang menimbulkan munculnya konflik sosial dalam masyarakat, maka akan diberi sanksi sesuai ketentuan yang diatur dalam pranata Surat Tumbaga Holing.

Setiap peraturan adat yang tidak boleh dilanggar disebut patik. Patik adalah nilai mengenai benar dan salah yang merupakan kumpulan asas atau nilai yang berkenaan dengan akhlak. Jadi patik adalah etika prilaku orang batak, baik sebagai anggota keluarga maupun sebagai anggota masyarakat (Harahap, 1993: 85-86).

Sedangkan ugari adalah kebiasaan yang diangkat sebagai peraturan selama tidak merusak adat-istiadat yang berlaku sebagaimna tertuang dalam patik. Sedangkan uhum adalah sanksi hukum terhadap pelanggaran atas peraturan adat, seperti patik, ugari dan hapantunon. Uhum atau sanksi pelanggaran adalah bertingkat-tingkat. Pada umumnya terdapat 3 (tiga) macam jenis sanksi dalam masyarakat adat di Tapanuli Bagian Selatan, yakni (Harahap, 1991: xv.): 1) Sanksi yang dijatuhkan berdasarkan hasil keputusan sidang adat; 2) Sanksi yang dijatuhkan dengan pembayaran denda; 3) Sanksi yang dijatuhkan berupa nasehat dari pihak harajaon dan hatobangon. Sanksi jenis ini hanya berlaku pada jenis pelanggaran ringan.
Setiap pelanggaran adat selalu mendapat sanksi sesuai dengan ketentuan adat. Adapun jenis sanksi yang dijatuhkan adalah bervariasi tergantung berat ringannya pelanggaran dan kejahatan yang dilakukan seseorang (Harahap, 1993: 28).

Dalam setiap pelanggaran atau kejahatan yang dilakukan di tengah- tengah masyarakat, telah ada aturan jenis sanksinya sebagaimana yang telah tertuang dalam Surat Tumbaga Holing yang menjadi sumber rujukan hukum adat masyarakat adat Batak.

Dengan demikian, ada beberapa bentuk sanksi yang dijatuhkan kepada orang yang memicu timbulnya konflik sosial dalam masyarakat: pertama adalah Mangido Maaf, yaitu jenis sanksi ini merupakan sanksi yang pertama dan paling rendah dalam masyarakat Batak Muslim di Tapanuli Bagian Selatan. Semua jenis pelanggaran yang dilakukan oleh masyarakat yang bersifat ringan dan tidak mengganggu ketertiban umum/kepentingan masyarakat adat dan juga tidak melanggar norma agama, hukum dan kesusilaan, maka pelakunya dapat dijatuhi sanksi berupa minta maaf sebagai konsekuensi pengakuan atas kesalahan yang dilakukan dan berjanji tidak akan mengulangi perbuatan yang sama pada masa mendatang;

Kedua adalah Mangalehen Denda atau lebih dikenah dengan istilah Uhum Hora. Sanksi jenis ini merupakan sanksi yang tidak begitu berat, melainkan hanya sebagai wujud tanggung jawab atas berbagai kesalahan yang dilakukan. Ketigs, adalah Sappal Dila. Jenis sanksi ini merupakan jenis sanksi yang agak berat, jika dibandingkan dengan sanksi pada jenis pertama. Adapun yang dimaksud dengan sanksi Sappal Dila adalah suatu jenis hukuman yang menuntut pelakunya untuk memotong seekor kambing atau kerbau/lembu dengan mengundang makan orang sekampung untuk melakukan permintaan maaf di muka Harajaon, Hatobangon, ulama dan masyarakat adat Dalihan na Tolu.

Sanksi Sappal Dila ini terdiri dari beberapa macam, yakni: Uhum Horbo Mate (Sanksi seekor kerbau untuk disembelih); Uhum 
Horbo Mangolu (Sanksi seekor kerbau yang masih hidup); Uhum Mate Mangolu (sanksi berupa pemberian 2 ekor kerbau dimana yang seekor disembelih dan seekor yang lain tetap hidup); Uhum Horbo Tailpa (sanksi berupa seekor kerbau dan beberapa geram emas).

Keempat adalah dibondarkon. maksudnya adalah orang yang tidak mentaati hasil putusan majelis adat tersebut tidak diikutkan dalam segala kegiatan dalam masyarakat adat. Seolaholah ia dianggap sudah tidak ada lagi. Sebaliknya jika ia hendak melakukan suatu kegiatan baik dalam bentuk siriaon maupun dalam bentuk siluluton tidak bias dilaksanakan dengan menggunakan tatacara adapt setempat. Biasanya orang yang mendapat hukuman dalam jenis mambondarkon ini adalah tidak bertahan lama, pada akhirnya ia akan minta maaf pada hartobangon dan para raja dengan berjanji untuk mentaati segala keputusan majelis adat di masa-masa yang akan datang;

Kelima, adalah dikeluarkan dari Huta. Hukuman pada tingkat ini dilaksanakan, jika tahap hukuman yang pertama saja ia tidak jera, malah ia cenderung melecehkan dan menghasut masyarakat untuk tidak mematuhi putusan majelis adat. Orang seperti ini diberi uhum berupa pengusiran dari kampung itu sendiri. Ia harus segera dan berangkat menuju kampung lain. Ia tidak boleh lagi tinggal di kampung itu setelah putusan pengusiran dijatuhkan. Lain halnya kalau ia minta maaf, maka diberikan kesempatan padanya untuk memperbaiki diri. Dalam proses permintaan maaf tersebut, ia harus mengundang makan orang sekampung dengan menyembelih seekor kambing. Dalam acara tersebutlah ia sampaikan permintaan maafnya atas kesalahannya selama ini;

Keenam, adalah ditarik tanah Salipi Natartar. Adapun yang dimaksud dengan sanksi jenis ini adalah suatu jenis sanksi berupa penarikan tanah ulayat/tanah adat yang diberikan Raja kepada seseorang sebagai hak pakai saja yang akan dipergunakan sebagai tempat pertanian atau perkebunannya dalam suatu perkampungan di lingkungan satu Luat (satu daerah kekuasaan). Tanah Salipi Natartar hanya bisa ditarik dalam keadaan: a)
Penggarap tanahnya sudah menjadi kaya, b) karena pemegang tanah Salipi Natartar berpindah kampung/tempat tinggal, c) karena melakukan pelanggaran adat; Ketujuh, adalah dikeluarkan dari Marga. Jenis sanksi ini merupakan jenis yang sangat berat, karena penarikan atau pencopotan sebuah Marga merupakan sesuatu penurunan harga diri dan derajat seseorang di tengah-tengah masyarakat.

Ada beberapa alasan yang menjadikan sanksi ini menjadi berat yakni: a) Pencopotan Marga berarti pencopotan silsilah seseorang dari keturunannya. Konsekuensinya, adalah hubungan kekeluargaannya dengan marganya dianggap sudah tidak pernah ada lagi dan ia dianggap menjadi hidup sebatangkara yang tidak punya marga; b) Pencopotan Marga berarti pencopotan seluruh fasilitas yang diberikan adat kepadanya, seperti gelar kerajaan, pemakaian tanah adat dan lainnya; d) Pencopotan Marga berarti pencopotan marga anaknya sendiri.

Kedelapan, adalah Uhum Pasung, yakni sanksi berupa pemasungan terhadap pelaku tindak kejahatan dan pelanggaran di tengahtengah masyarakat adat; Kesembilan adalah Uhum Hatoban. Suatu sanksi berupa penjatuhan martabatnya sebagai budak dalam waktu tertentu sesuai dengan hasil keputusan dalam masyarakat adat; Kesepuluh, adalah Uhum Rampas Barang. Suatu sanksi berupa penarikan semua barang milik si pelaku yang jumlahnya disesuaikan dengan hasil keputusan dalam masyarakat adat;

Kesebelas, adalah Disula, artinya dihukum mati melalui tusukan kayu di dalam perut dan tubuhnya. Operasionalisasinya adalah ditusukkan badan pelaku tindak pidana adat ke atas kayu runcing lagi tajam yang telah ditanam terlebih dahulu. Sanksi disula juga diistilahkan dengan uhum mate, yang berarti penjatuhan sanksi berupa hukuman mati (Managor, 1995: 47).

Hukuman jenis ini hanya diberlakukan bagi pelaku tindak pidana pembunuhan, di luar itu tidak diperkenankan menjatuhkan hukuman jenis ini. Penjatuhan hukuman sula (mati) adalah hanya dilakukan bagi pelaku pembunuhan sengaja dan berencana, 
sedangkan pembunuhan tersalah, tidak dikenai hukuman mati. Oleh karenanya, hukum adat Tapanuli Selatan benar-benar selektif dan hati-hati dalam menerapkan dan menjatuhkan setiap jenis hukuman, termasuk hukuman mati.

Ada beberapa tindakan dalam masyarakat adat yang layak dan pantas dijatuhi sanksi sebagaimana yang telah diberlakukan pada jaman nenek moyang terdahulu, yakni: Pertama adalah Mangaloasi Patik. Kesalahan melanggar peraturan yang ditetapkan raja. Pelanggaran jenis ini berupa sanksi setinggitingginya 3 hari dipasung atau didenda 10 real; Kedua adalah Sirambas Nadugul. Suatu tindakan yang jahil dan kurang tertib di tengah-tengah masyarakat. Dapat dihukum setinggi-tingginya 10 real atau hukuman poasung selama 4 hari; Ketiga adalah Sitinjo Bubungan. Suatu pelanggaran berupa peninggian diri seolah- olah ia di atas orang tua, maka ia dijatuhi sanksi berupa denda setinggi-tingginya 20 real atau hukuman pasung setinggi-tingginya 10 hari; Keempat adalah Natcecul di Banua atau Pamasuk Aili. Suatu jenis kesalahan berupa mengadu domba, supaya timbul perang yang bertujuan membunuh raja atau orang-orang bangsawan. Jenis kejahatan ini dapat dihukum mati;

Kelima adalah Pangalantuk panggetegete atau disebut juga tukang latlut. Suatu jenis kesalahan berupa mengadu domba orang supaya berkelahi. Dan jika perkelahian itu mengakbatkan kematian, maka yang menghasut dapat dihukum mati; Keenam adalah Teas adalah berupa penghinaan. Siapa yang menghina raja atau bangsawan dapat dihukum setinggi-tingginya 5 bulan atau dapat dijadikan budak. Bila penghinaan dilakukan terhadap Situan na Torop (rakyat banyak) dapat dipasung selama 5 hari; Ketujuh adalah Janglas. Penghinaan ringan. Penjatuhan sanksi setinggi-tingginya 3 hari dipasung;

Kedelapan adalah Sitimba Paya, yaitu pabila seorang mora melakukan penganiayaan berat atau menghamili gadis keluarganya dapat dijatuhi sanksi berupa memotong seekor kerbau atau kambing untuk menjamu masyarakat dan meminta maaf; kesembilan adalah Sirahar Padang. Apabila seorang bangsawan melakukan penganiayaan berat atau anaknya hamil tanpa nikah dapat dijatuhi sanksi berupa memotong seekor kerbau untuk menjamu masyarakat dan anaknya yang hamil segera dikawinkan.

Rincian sanksinya sebagai berikut: 1) Terhadap pelaku penganiayaan harus menjamu makan keluarga yang teraniaya sambil berdamai meminta maaf dan menanggung makanan si teraniaya selama sakitnya; 2) Bila anak gadisnya hamil, ia harus menjamu Bona Bulu sambil mengaku kesalahannya bahwa ia kurang jaga terhadap anaknya; 3) Anak Borunya diberi sanksi berupa memotong seekor kambing untuk menjamu penduduk karena kurang jaga terhadap anak gadis moranya. 4) Markarosuan. Apabila seseorang berjina dengan seorang janda, maka dijatuhi sanksi pasung selama 3 hari; 5) Satu Garung Dua Sayatan. Barang siapa melakukan perjinahan dengan isteri orang lain, maka dijatuhi sanksi setinggi-tingginya 1 tahun jagung; 6) Tardege Panggul ni Dalan. Barang siapa yang memperkosa wanita, dihukum 1 tahun jagung. Perkosaan terhadap anak di bawahumur akan dijatuhi sanksi berupa dipasung selama 1 tahun jagung dan setelah selesai menjalani hukuman ia dijadikan budak; 7) Sumbang. Barang siapa yang kawin semarga amak dijatuhi sanksi berupa dipisahkan antara keduanya; 8) Rompak Tutur. Barang siapa yang kawin dengan anak saudara paman, yang dalam partuturon dipanggil pahompu atau yang sejajar dengan dia. Dijatuhi sanksi dengan menyembelih seekor kambing untuk menjamu namora hatobangon dan pada waktu itu dirubah tutur mereka; 9) Apabila seorang gadis atas kemauannya sendiri dibawa olen calon suami ke rumah orang tuanya atau ke rumah keluarganya dan kemudian sabng gadis menyesal dan meminta untuk kembali ke rumah orang tuanya, maka keluarga sang gadis dijatuhi sanksi berupa pasung selama 2 hari; 10) Nada Markilap Marronggur. Barang siapa melarikan gadis bangsawan walau atas kemauannya sendiri dengan maksud untuk dikawini dan 
kepergian gadis itu tidak menurut adat, maka dijatuhi sanksi berupa pemberian 2 ekor kerbau. Seekor kerbau disembelih untuk menjamu Namora Hatobangon dan penduduk guna minta maaf serta mengelilingi bagas godang sebanyak 7 kali dengan bergandeng oleh ibu-ibu dan para gadis pihak yang melarikan gadis itu; 11) Burangir na Hombang. Pelanggaran adapt berupa kurang sopan santun atau tata tertib terhadap namora dijatuhi sanksi berupa minta maaf atau dihukum pasung 1 hari; 12) Parsiruhuon (membersihkan mulut). Barang siapa yang menuduh seseorang menyimpan racun, pencuri, budak dan lainnya yang pada hakekatnya tidak benar, sehingga yang dituduh malu karenanya, dijatuhi sanksi berupa menyembelih seekor kambing untuk menjamu orang yang dituduh dan penduduk, sambil meminta maaf dan berdamai; 13) Amporik humorkor. Apabila gadis bangsawan atau keluarga wanita raja saudara ataupun namora melakukan perbuatan yang dilarang adat sampai "digora-gora pidong marboritan". Mora dan anak borunya dijatuhi sanksi berupa penyembelihan seekor kerbau untuk menjamu penduduk, karena mereka kurang jaga terhadap gadis itu dan untuk membersihkan bona bulu, gadis tersebut dikawinkan dengan anak namborunya; 14) Sampal Bibir. Barang siapa yang mengeluarkan perkataan yang tidak senonoh terhadap seseorang, maka dijatuhi sanksi berupa penyembelihan seekor kambing untuk menjamu penduduk sekalian minta maaf; 15) Haijuran. Barang siapa yang menceraikan isterinya tanpa suatu alasan, maka dijatuhi sanksi berupa membayar 2 kayu besi. Sekayu untuk keluarga perempuan dan sekayu lagi untuk kerajaan yang diperuntukkan untuk membuat senjata. Sanksi yang sama juga dijatuhkan kepada orang yang membawa gadis ke rumahnya dengan maksud untuk dinikahinya dan keluarganya tidak mau menerimanya; 16) Barang siapa yang menceraikan isterinya bukan karena berzina, maka dijatuhi sanksi berupa denda 2 kayu besi; 17) Mangadatkon Naso Adat. Barang siapa membuat pesta tidak menurut peraturan adat, maka dijatuhi sanksi berupa penyembelihan seekor kerbau untuk menjamu namora hatobangon dan masyarakat untuk meminta maaf sambil mengelilingi rumah raja sebanyak 7 kali bersama ibu-ibu dan para gadis dari keluarga yang bersalah; 19) Pangkupangi. Apabila si tuan na torop (orang banyak) memakai adat yang bukan adatnya, maka dijatuhi sanksi berupa penyembelihan seekor kambing; 20) Habong ni Onggang. Barang siapa memakai kain kebesaran adat, yakni kain sadun, maka dijatuhi sanksi berupa pemberian seekor kambing atau kerbau untuk kerajaan dan kain sadun tersebut disita; 21) Sabur Taroktok. Barang siapa membuat keributan, hiruk pikuk atau menggemparkan masyarakat yang dapat membuat orang lain terkejut, maka dijatuhi sanksi berupa pasung setinggi-tingginya 1 bulan; 22) Panoptop. Barang siapa dengan tidak sengaja karena kelalaiannya, terbakar rumah orang lain, maka dijatuhi sanksi berupa penyembelihan seekor kambing untuk menjamu orang sekampung sambil minta maaf dan darah kambing itu disiramkan ke tanah tempat rumah yang terbakar itu; 23) Manunu atau Mayurkut. Barang siapa yang manunu (membakar) kampung, maka dijatuhi sanksi berupa berupa hukuman mati; 24) Manuk Laki Bini. Barang siapa yang merusak harta benda orang lain dengan tidak sengaja, maka dijatuhi sanksi berupa pemberian ayam jantan dan betide kepada pemilik harta; 25) Sitangko $B u b u$. Barangsiapa mencuri lukah (bubu), maka dijatuhi sanksi berupa membayar padi sebanyak 2 kali isi lukah (Managor, 1995: 4758). Setelah diputuskan jenis sanksi yang diberikan kepada pelaku kejahatan dan pelanggaran, maka semua hasil keputusan dan jenis sanksinya diberitahukan ke seluruh masyarakat dengan memukul gong pada malam hari sambil membacakan hasil keputusannya dengan bersuara keras.

Ada berbagai kasus yang tercatat dalam arsip-arsip vonis rapat adat di Tapanuli Selatan. Kasus yang diuraikan meliputi masa akhir abad yang lalu sampai menjelang akhir masa penjajahan Belanda. Beberapa kasus yang dimaksud adalah (Harahap, 1993: 544-551): 
Pertama, vonis adat, tanggal 23 Agustus 1919 di Batang Toru tentang hukuman kepada anak gadis yang mungkir janji untuk kawin lari dengan seorang pemuda. Sebelumnya kedua remaja ini telah sepakat akan melangsungkan kawin lari. Sebagai tanda kesetiaan, mereka telah melakukan patimbang barang (pertukaran barang). Pihak laki-laki telah memberikan barang-barang berupa: sehelai kain sarung berkepla merah tua seharga f 9, sebuah arloji nikel pakai rantai suasa dengan mainan uang mas seharga $\mathrm{f} 43$, baju partanding kain sende jantang seharga f 11 dan uang pandokdok f 2 dan 2 kepeng. (Kepeng adalah nama mata uang jaman dahulu yang nilainya sama dengan setengah duit. Satu rupiah zaman dahulu sama dengan 120 duit atau 240 kepeng.) Gadis itu memberikan tusuk konde dari suasa seharga f 10. Sang pemuda mengadukan gadis yang murkir itu ke siding adapt. Setelah mendengar dua orang saksi, maka siding adapt memutuskan agar gadis itu membayar f 43 sebagai pengganti arloji yang sudah tidak ada lagi, sedangkan barang-barang lainnya dikembalikan kepada si pemuda. Demikian juga pemuda itu mengembalikan tusuk konde yang pernah diterimanya dari gadis tersebut;

Kedua, vonis adat di Sipirok, tanggal 11 Maret 1923 tentang pengembalian uang jujuran oleh pihak perempuan karena telah terjadi perceraian; 1) Vonis adat di Sipirok, tangal 19 Desember 1923 tentang tuntutan Raja Pamusuk kepada seorang penduduk yang belum membayar hak Raja Pamusuk dan hatobangon berupa na muhut ketika orang tersebut menikahkan anak gadisnya. Orang tua gadis itu menyatakan di dalam sidang adat bahwa ada tiga alasannya mengapa ia belum membayar na muhut, yakni: karena dia masih sakit, karena pihak laki-laki belum menyerahkan na muhut kepadanya, dank arena perkawinan itu belum dilaksanakan secara adapt. Vonis yang dijatuhkan adalah: terdakwa harus membayar na muhut kepada raja, karena hal itu perlu untuk kerukunan di dalam huta;
2) Rapat adat tanggal, 19 Februari 1929 di Padangsidimpuan memeriksa perkara pengaduan permintaan kembali uang jujuran oleh seorang tua kepada moranya, karena anak orang tua tersebut meninggal setelah 18 tahun menikah dengan anak perempuan moranya. Janda itu kemudian dinikahkan oleh orang tuanya kepada laki-laki lain tanpa mufakat dari orangtua suami yang meninggal itu. Jujuran yang dituntutnya untuk dikembalikan sebanyak f 160 , yaitu sejumlah yang pernah diberikannya kepada orang tua si gadis itu dahulu. Rincian jumlah uang itu adalah f 80uang kontan, f 60 untuk pembeli seekor kerbau dan f 20 untuk pembeli seeekor lembu untuk pesta pernikahan anaknya dahulu. Jumlah itulah yang dituntutnya untuk dikembalikan oleh moranya itu. Vonis menyatakan bahwa pendakwa tidak berhak meminta jujuran kepada moranya, karena janda itu kawin dengan laki-laki dari kalangan pendakwa. Jadi pengembalian jujuran semestinya diminta kepada suami baru tersebut;

3) Mengenai kawin semarga pernah dimuat oleh Koran terbitan Surabaya Soeara Publiek pertengan tahun 1925 dengan judul "Adetterreur (terror adat)" yang terjadi di Angkola Jae. Orang tua gadis dihukum secara adat. Ada lima tuntutan kepadanya, yaitu: a) Memotong kerbau untuk pesta adat sekampung, karena telah melaksanakan pernikahan sumbang; b) Menghukum orang tua pihak laki-laki dengan hokum yang sama sebagaimna dijatuhkan kepada orang tua si gadis; c) Kedua pengantin harus diceraikan; d) Mengeluarkan orang tua perempuan dari masyarakat adat; e) Mengusir orang tua perempuan dari kampung itu.

Ketiga, rapat adat di Pangabungan pada hari Kamis, 17 Januari 1895. Rapat ini dilanjutkan lagi pada hari Selasa tanggal, 20 Januari 1895 tentang pemeriksaan perkara seorang gadis manyompo. Rapat ini dipimpin oleh kontrolir Mandailing Besar dan Batang Natal yang dihadiri oleh Raja Panusunan Bulung dan Raja Pamusuk, yaitu Sutan Mandailing dari Gunung Tua, Tuan maha raja Sian dari Panyabungan Tonga, Sutan Mangguyang dari Pidoli Bukit, Baginda 
Soalohon dari Panyabungan Julu, Sutan Mangasa Pintor dari Maga dan Mangaraja Gunung Malea dari Gunung Baringin. Sebelum peristiwa manyompo ini sebenarnya antara anak gadis dan pemuda tunangannya sudah pernah berimbang barang dan hari pernikahan sudah ditentukan. Tetapi gadis itu mungkir dengan mengembalikan semua barang tunangannya dan dia lari ke rumah pemuda pilihannya. Pemuda pilihannya itu sudah pernah mengutus orang tua untuk menyatakan ulang agoan ke keluarga pihak gadis. Oleh karena itu, pihak orang tua gadis mengutus kerabatnya ke rumah pemuda itu untuk menarik kembali gadis itu. Gadis itu bertahan tidak mau kembali ke rumah orang tuanya. Pemuda itu sendiri meminta nasehat utusan kerabat gadis itu bagaimana caranya agar mereka dapat menikah. Setelah mendengar semua yang terlibat, dua orang pemuda dan seorang gadis, serta orang tua gadis, maka rapat adat memutuskan bahwa menghukum pemuda yang dipilih gadis itu untuk memotong kerbau dan menjamu Kuria Huta Siantar, kepala kampong, kepala ripe, orangorang tua dari kampong pemuda itu. Selain itu pemuda itu harus mengantarkan kembali gadis itu ke rumah orang tuanya. Ini harus sudah dipotong setelah delapan hari tanggal keputusan rapat adat;

Keempat, adalah vonis rapat adat di Panyabungan Tonga, atas pernikahan sumbang atau perkawinan semarga. Peristiwa ini terjadi pernikahan antara seorang bermarga Nasution Lancat dengan Nasution Tambangan. Selain itu salah seorang undangan juga melarang tuan rumah memakai kain adat hitam bermanikmanik sebelah, karena dia tidak berhak memakainya. Peristiwa ini diadukan kepada Kuria Huta Siantar yang menyebabkan orang tua yang menikahkan itu, dihukum memotong seekor kambing dan tidak boleh memakai kain adat itu. Tetapi rapat pada hari Selasa, 29 September 1896 memutuskan bahwa pernikahan itu sah karena terbukti kedua pengantin mempunyai marga yang berbeda yaitu ancat dan Tambangan, jadi keduanya bukan Nasution. Selain itu orang tua boleh memakai kain yang bermanik-manik sebelah sisi dan dibebaskan dari hukuman memotong seekor kambing karena terbukti tidak menyalahi aturan adat;

Kelima, adalah rapat adat hari Rabu, 28 Agustus 1895 tentang perampasan kambing yang sudah dipotong dan siap dimasak dalam rangka upacara adat perkawinan. Tiga orang yang menampar menuduh si pemilik memberikan tulan rincan kambing ke alamat yang salah. Menurut ketiga perampas itu tulan rincan harus diberikan kepada kepala kampong lain di dekat kampong itu, karena kepala kampong itu yang berhak. Sedangkan si pemilik menyerahkan tulan rincan kepada Raja si Oban Ripe di kampungnya sendiri yang dianggap melanggar adat oleh ketiga perampas itu. Rapat memutuskan agar ketiga perampas itu dihukum dengan memotong seekor kerbau dan membayar ganti rugi atas segala bumbu masak yang tidak terpakai;

Keenam, adalah rapat adat di Huristak, 6 Januari 1923 yang banding dua setengah tahun dan rapat adat di Gunung Tua, 29 Juli 1926 memutuskan perkara pembukaan kampung Tobing Dolok Partapaan yang diperjuangkan oleh Mangaraja Palaon melawan Patuan Barumun (kepala Luhat Huristak). Pasalnya adalah ketika Mangaraja Palaon hendak menyelenggarakan pesta besar pernikahan puteranya ternyata dilarang oleh Patuan Barumun, karena Mangaja Palaon sebelumnya belum perbnah menyelenggarakan pesta adat besarberhubung hutanya belum diakui sebagai huta. Oleh karena itu Mangara Palaon dihukum dengan memotong kerbau dan memberi makan kepala kuria dan harajaon;

Ketujuh, adalah vonis rapat adat, 4 Nopember 1924 di Sibuhuan tentang penyelenggaraan pesta perkawinan dengan memotong kerbau diteruskan dengan mangampeon goar sutan, tongku dan mangaraja, tanpa meminta ijin kepada kepala Luat Sosa Julu. Tuduhan yang disamikan adalah melaksanakan horja tanpa setahu kepala luat dan memberi gelas yang tidak menjadi haknya. Setelah banyak mendengar saksi dari kepala kampong di wilayah Luat Sosa Julu, maka yang didakwa itu dihukum dengan menyembelih seekor kerbau sebagai pengakuan bersalah dan 
juga memberimakan kepada Kela Luat dan rajaraja di daerah itu. Kalau vonis ini tidak dilaksanakan maka terdakwa akan dikucilkan dari masyarakat adat. Terdakwa naik banding dan mengadukan masalah ini kepada Residen Tapanuli di Sibolga. Ternyata Residen Tapanuli malah mengukuhkan keputusan rapat adat itu.

\section{SIMPULAN}

Sanksi yang dijatuhkan kepada orang yang memicu timbulnya konflik sosial dalam masyarakat: Minta Maaf (Mangido Maaf), membayar denda (Mangalehen Denda), Sanksi Moril (Sappal Dila), Tidak Dilibatkan dalam Kegiatan Adat (Dibondarkon), Dikeluarkan dari Kampung, Ditarik Fasilitas yang Diberikan Adat (Ditarik Tanah Salipi Natartar), Dikeluarkan dari Marga, Diturunkan martabat adatnya (Uhum Hatoban).

\section{DAFTAR PUSTAKA}

Adi. R., (2010). Metodologi Penelitian Sosial dan Hukum. Edisi Ketiga. Granit. Jakarta.

Ali. Z., (2008). Sosiologi Hukum. Cetakan 4. Sinar Grafika. Jakarta.

Arfa, F.A., (2010). Metodologi Penelitian Hukum Islam. cetakan 1. Citapustaka Media Perintis. Bandung.

Bungin, B., (2012). Analisis Data Penelitian Kualitatif. Cetakan 8. PT Raja Grafindo Persada. Jakarta.
Harahap, A., (1991), Gelar Bagindo Raja Harahap, Poda-Poda Ni Adat, Padang Sidempuan: Pustaka Rahmat.

Harahap, A.S., (2013). Pengaturan Hukum Penyelesaian Sengketa Pemilihan Kepala Daerah Berbasis Dalihan na Tolu. Jurnal Kalam Keadilan. 1 (3).

Harahap, P.M., (1993), Horja: Adat Istiadat Dalihan Natolu, Jakarta: Parsadaan Marga Harahap Dohot Anak Boruna.

Ilyas. (2014). Kajian Penyelesaian Konflik antar Desa Berbasis Kearifan Lokal di Kabupaten Sigi, Sulawesi Tengah. JURNAL ACADEMICA. .06 (01).

Jati, W.R., (2013). Kearifan Lokal Sebagai Resolusi Konflik Keagamaan. Jurnal Walisongo. 21 (2).

Kuntjara. E., (2006). Penelitian Kebudayaan. Cetakan 1. Graha Ilmu. Yogyakarta.

Machan, T.R., dengan penerjemah Masri Maris. (2006). Kebebasan dan Kebudayaan. Yayasan Obor Indonesia. Jakarta.

Managor, S. (1995). Pastak-Pastak Ni Paradaton Masyarakat Tapanuli Selatan. Tanpa Penerbit.

Sriyanto. A., (2007). Penyelesaian Konflik Berbasis Budaya Lokal. Jurnal Ibda. 5 (2).

Sugiono, (2010). Metode Penelitian Kuantitatif Kualitatif dan R\&D. Cetakan ke-10. Alfabeta. Bandung.

Sunggono. B., (1998). Metodologi Penelitian Hukum. PT. Raja Grafindo Persada. Jakarta.

Undang-undang Nomor 7 Tahun 2012 Tentang Pencegahan Konflik Sosial.

Wijayanti, A., dan Lilik S.A., (2011). Strategi Penulisan Hukum. Cetakan 1. CV. Lubuk Agung. Bandung. 